\title{
Traditional urbanism and lessons for global cities: the case of Isfahan
}

\author{
B. A. Kazimee \\ School of Architecture, Washington State University, USA
}

\begin{abstract}
This paper is about a discussion and a record on the ways traditional places can help us re-establish meaning and a sense of belonging, in a world now increasingly defined by pointlessness. The traditional city of Isfahan is selected for discussion and analysis because Isfahan, through its methodical urban development, maintained a balance that stood between nature, culture and society and is the result of an evolving process through many generations. With its marvelous architecture, of pavilions, gardens, mosques and lavish ornamental profusion of building facades, Isfahan bears the hallmark of a culture and architecture that provides us with lessons of history and opens up for us the imaginative myth of human consciousness. Traditional architecture and planning is adoptable to our modern needs and aspiration and can enrich our lives beyond the material and mechanical capacity.

Keywords: traditional city, nature, culture/society, architecture and urbanism.
\end{abstract}

\section{Introduction}

In our current time the spirit of the modern city is one of globalism. This theme perpetuates itself at all levels of society from the work place, to the market, to transportation, to entertainment and architecture. No matter where one travels, modern cities are no longer organized according to regional identity, but rather to a manner that is ephemeral and without a sense of history.

During the last century, the modern world has been on a course of persistent change and innovation. The desire, to see truth as strictly the product of rational constructions, has given rise to a world in which rituals, myths and traditions in general are at best interesting relics of the past and at worst invalid and marginal. Once the tradition is seen in a residual as opposed to cyclical terms, tradition 
then falls prey to irrelevancy. In this sense, tradition is associated with backwardness, lack of creativity, boredom and stagnation. Edward Shills warns about the damaging effects that the cult of scientism has had on tradition, and says that in seeing itself as the sole harbinger of originality and thus progress, it has unnecessarily devalued the role of the past [1]. The transient and alien city condition is nothing new and has been with us for at least the last one hundred years. One of the issues that impelled the Dadaists into radical action at the outset of the $20^{\text {th }}$ century, for instance, was their view that the city had become such a rational, mechanical entity, that there was little room for us to intuit in it [2]. Their option to work with montage was in effect to exemplify the breakdown of traditional unities that had constituted the web of daily events. Cause and effect were no longer as tightly connected as before and in some cases had already broken apart completely.

Tradition itself, at the end, is not in essence about dogma, but about shedding light on knowing our place in the community, our shared history and giving us guidance as to the dignified manner with which we need to engage each other and all the environment around us. In fact, traditional places are more than physical entities, one should become exposed to a survey of life in its totality. Heidegger revered such places as the cultivation of identity and saw in the idea of "building," the origin of neighborliness, signaling for us a conviction that place is not about change but about staying, cultivating, repeating; in short about tradition itself [3].

We have grown so accustomed to thinking of history in spectacular terms, incidents that the judges of culture and scholarship have considered worthy of our attention, but which we have no practical use for it any more outside the realm of interest and curiosity [4]. History in this sense is a body of information that we engage ourselves with from a distance in time and place, or perhaps even strengthening our appeal for a nostalgic time. To traditional cultures, history never fades away but is persistently exercised as a way of enriching our lives and passing on critical knowledge. There is of course history in the grand sense of epoch formation and a singular object or an image that outshines the rest, but that does not deter us from the fact that smaller histories are daily siphoned through as a matter of keeping the culture alive [4]. Whether through the telling of stories or through the passing of practical knowledge, the emotional and intellectual span between one generation and the next is never severed.

\section{The case of Isfahan}

Rich in culture, art and architecture, Isfahan maintains a poignant position and pride of traditional architectural legacy amongst traditional Islamic cities. Isfahan tells us much about why an authentic "sense of place" is necessary to our experiential identity and intellectual capacity, particularly in the Islamic tradition. The cosmopolitan city of Isfahan, much of its urban development that dates back to the early $17^{\text {th }}$ century, a time when the Safavid dynasty ruled the city, but also one in which various global forces had begun to converge on the 
region: British-India and China from the east and the Ottomans and Imperial Europe from the west. Due to its unified and dynamic urban structure, Isfahan synthesized faithfully the changing economic and political global role of $17^{\text {th }}$ century and yet it preserved successfully its subtle cultural and historical affluence.

Having served as an important political and administrative center during the Seljuk dynasty in the $11^{\text {th }}$ century, the city later witnessed the dismal misfortunes of war, distraction and massacres during the Mongol and Timurid periods of the $13^{\text {th }}$ and $14^{\text {th }}$ centuries, but Isfahan would regain its splendid importance again during the Safavidin $17^{\text {th }}$ century. During this period ambitious building programs were initiated with the construction of magnificent mosques, public gardens (char-baghs), bridges, caravansaries and urban plazas (Maidan). At its height Isfahan is reputed to have had over 160 mosques, nearly 50 madrases, 1,800 caravanserais, 273 bath-houses (hammams) and numerous glittering gardens and covered bazaars [5]. It is estimated that the population of Isfahan at this time was 500,000 inhabitants. [6]

In urban terms, Isfahan is built around the boundaries of three types of architecture order: the square called the maidan, the thoroughfares, known as $k u c h a$, and the dense clusters of residential districts, the mahala. Depending on the degree of enclosure, each property offers specific spatial qualities that constitute points of departure for these urban forms. The particularity of how these places are used is clearly the job of culture and is locally determined. Internally these places contain sub-places, which serve different purposes in the settlements. Here we find the essence of in-between with its artifacts that define the innermost goals, and their various structural properties that clearly emphasize the form of life.

The construction of the new city during ShaAbas's reign (1587-1628) begins around the Great Square (Maidan-i-Shah) to the southwest of the old city. The new Maidan functioned as a polo ground, a public square for caravans and an open marketplace for the villagers (Fig.1). ShaAbas established his center to the lower West Side of the Maidan, which already had a Timurid gatehouse, the AliQapu, or the high gate and constructed palaces and gardens scattered behind it to the west of the square. Ali Qapu holds the symbolic point of contact between the past on one hand and is a visual connecter between the private quarters of the palace and the public outside. While modest in term of facade appearance, this structure is in actuality a very elaborate work of six stories high, which served as the principle reception pavilion where ShaAbas received his courtiers and attended banquets (Fig.2). The eastern facade adjoining the great Maidan on the public side consists of a monumental gateway, which also permitted passage to the bazaar, encircling the entire square. On the upper floor above the gate stood the elaborate platform, talar, or loggia with sumptuous ornamentation. From here the king would attend and observe military parades and civil and religious activities that were a custom of the time. Probably the most important room in the building is the vast winter throne hall on the same level as the grand talar and extended as high as the talar roof. This room consists of a clerestory for light from above, decorated with rich patterns of stucco and Muqaranas (Fig.3). 


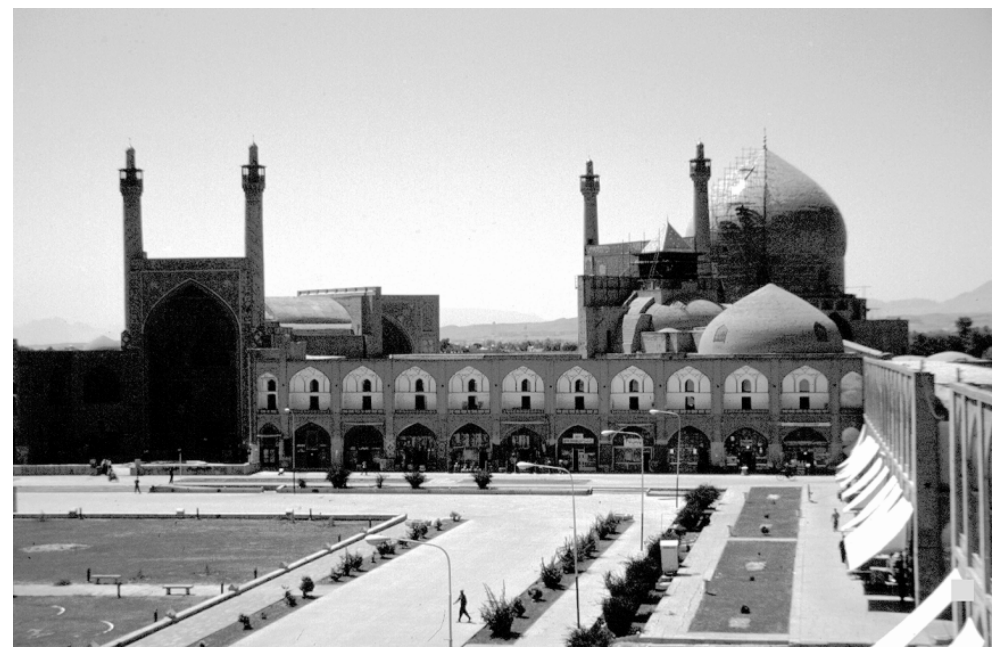

Figure 1: View of the southern end of the Maidan with Masjid-i-Shah in the background. Note, on the one hand, the wall separating the Maidan from the Masjid and the grand portal entryway on the left.

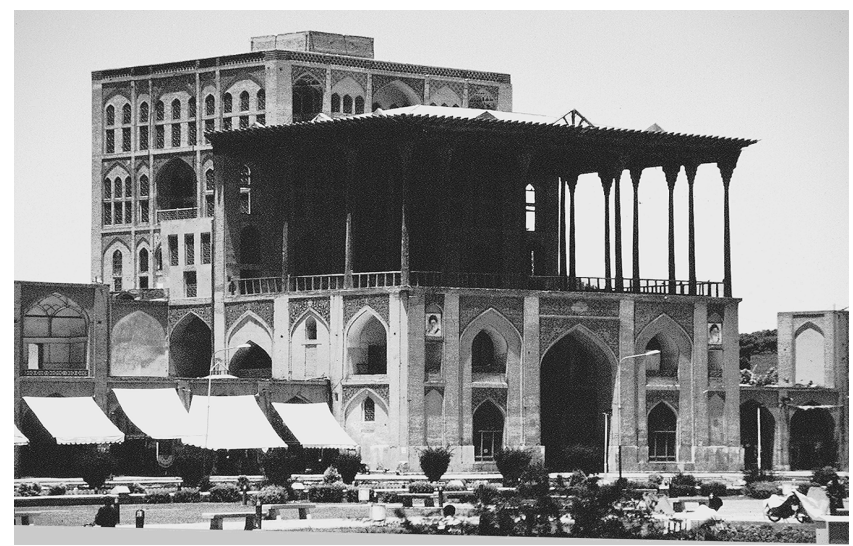

Figure 2: View of Ali-Qapu as it overlaps with the commercial arcade traversing longitudinally. Note the elaborate platform talar or loggia on the upper story overlooking the Maidan.

The rich pattern of natural light that penetrates through the arched clerestory windows admitted from above casts a playful interplay and mosaic of shadows [7].

Named after Sha-Abbas's father in law, Masjid-i-ShaykhLutfullah is situated directly opposite the Ali Qabu palace and to the lower east perimeter of the Maidan (Fig.4). The most unusual features of the mosque are the lack of minarets and central courtyard in direct contrast to that of Masjid-i-Sha. 


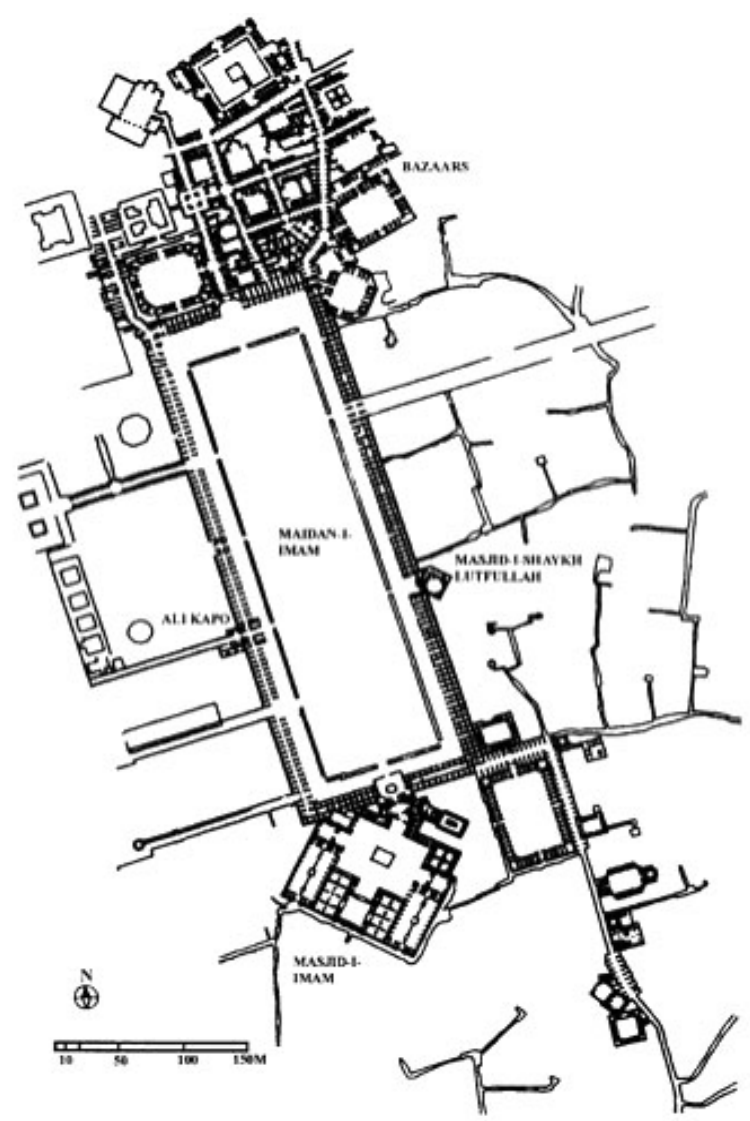

Figure 3: $\quad$ Plan of the Maidan-i-Imam, which provides passage to the bazaars encircling the entire square.

Entering the Masjid through a half domed portal entry Aiwan leads the worshippers to the main praying hall facing the Qibla and Mihrab. The main praying hall is covered with a magnificently decorated dome that sits on a welllit drum. The light enters through sixteen double grilled windows positioned proportionately around the drum.

In 1611 Shah Abas authorized the construction of the great mosque MasjidSha and it took 28 years to entirely complete the building. A grand entry portal allows passage to the mosque stands, which are about 90 feet tall and recessed deeply from the perimeter of the south wall of the Maidan, inviting the worshipers inside the mosque. Richly decorated with a mosaic of tiles and patterns of muqaranas, the portal provides remarkable sense of refinement and verticality.

Entering through the gateway one faces a critical transition of a long cavernous passageway and vestibule that are supported by intricate structures of arches and a vaulted ceiling. Unlike the overlap at the gatehouse, here unity is 
handled in terms of mass and void. When the passageway interacts with the entry portal of the Masjid there occurs the situation in which the mass is seen carved away and a void is made available. At this juncture the void is indicative of the fact that while in it you would neither be in the Maidan nor in the Masjid but in a unity between the two. The passageways gradually unfold and open up to the great central four aiwan courtyard of the mosque. The four-aiwan courtyard is a classical prototype, which has been in use since the architecture of the Timurid period and culminated a thousand years of evolution [8].

Inside the courtyard one is struck by a sense of tranquility amplified by encrusted blue colored tiles on the surrounding walls. As John D. Hoag remarks, "if the goal of Islamic Architectural ornament is the dissolution of the solid mass, it reaches perfection here" [9].

The gradual transition from open courtyard to the interior sanctuary which is located to the southwest of the courtyard, provides a structured and rhythmic transition. In the main sanctuary, all chambers are of square plan rising from the base on majestic piers arching at the top and form an octagon, from which subsequently through arching mechanism and the use of Muqaranas emerges the basic resolution of the circular dome. The circular band of the base of dome is embellished with colorful floral patterns, and Quraanic calligraphy [9].

The bazaar represents the primary movement system and commerce activity for the entire city. It commenced from the north gate and passed through the old Maidan, built during Suljuq period, and continued to expand during $16^{\text {th }}$ century Safavid to the south even further and terminated at Pul-Khwaju bridge built over the ZendaRud river.

Its moving system in the hierarchy of linear circulation links open booths, carvanserais, hammams and associated mosques together to the physiognomy of the whole city. In the Bazaar the traffic ways are sheltered from the sun by being completely covered. These partly or completely covered ways, however functional in the physical sense, also emphasizes the atmosphere of enclosure and seclusion to welcome the citizens [10].

Like most Islamic places, the world of commerce and the world of the mosque do not represent two distinct realities, often they are juxtaposed with each other. In Isfahan this view holds true, but only to a limited extend; namely that while business and religion stand to be at odds with each other, they do not constitute two distinct opposing realities but opposites within a singular reality. This is made clear by the way the wall between Maidan and Masjid is inhabited by merchants who sell their ware to those strolling around in the Maidan. Here we see the passageway, which had at one point skirted around and overlapped with the palace and then the Masjid-i-Lutfullah, now entering a new phase and playing the double role of edge and center simultaneously; edge to mosque and Maidan and center to market. As the three come together there arises the profound sensibility that while divisions in the way we live may be inevitable, these divisions need not be alienating but can be graced through the connective tissue of unity.

Residential quarters are fed by narrow and labyrinthine pathways that link the residential and private domain of courtyards to that of major network of bazaars 
and essential nodal activities. The narrow pathways abutting the courtyards get wider as they leave the residential precinct. Small shops, local mosques, and bathhouses are dispersed throughout the network of the pathway. These narrow networks as shaded by the masses of courtyards and walls provide condition of comfort for its user, which is very vital in the dry arid climate of Isfahan. Street intersections are small activity nodes where a small shop or a local mosque may be seen. A wider pocket in the corner may add to this communal and public function where male adults and elderly get together and socialize.

The intricate and compact orders of streets, which tend to show localized spaces, are the outgrowth of practical necessities. Street serves more than channels of mobility. Its complex territories are intensely three-dimensional and bordered by adjacent walls that add properties of verticality. The monotonous linearity of the thoroughfare is broken into smaller intimate sequences of spatial continuity that acquire a sense of individuality and place identity in every level.

The penetrated gateways, dahlans, underpasses, and building projections make the theme of kocha continues as unbroken container. The threedimensionality of container and its power of directional and thematic qualities accomplish something equal to the quality of interior. For the moment the pedestrian feels the intimacy and security of dwelling and exhilarating extension of their actions into the surrounding space. The effect of verticality is explicitly spelled out through narrow and continuous massing indicated by the gateways surmounted by projection from upper stories. An over pass dahlan, the minaret and elevated dome of the mosque each of them counterpoint and adds vertical accent to the horizontally of kucha.

Entry to the houses is normally indirect and exaggerated - entering this realm visitors find themselves first in a small entrance hall - but then one has to traverse long corridors (dahlan), before entering the courtyard. These entry halls provide access to several neighboring courtyards. The house gateway is often emphasized by the construction of monumental and sometimes highly decorated features. Metal and brass decoration and inscriptions, skeletal and bulkiness of doorway represent usual features and often-important indicator of the family status. The door serves to conceptualize the relationship of inside and outside and its position in the continuity of the massive wall, give emphasis to enclosure of the interior. This relationship creates an atmosphere of spirituality, which makes it meaningful, having direct contact with the substance of culture. The doorway offers us entry to the house but at the same time stops us to pause and think which is a temporary suspension of our passage to inside.

Passing the entry dahlan at the center stands haweli, the courtyard - the heart and the locus of the domestic life. Haweli makes the total amalgamation of inbetween places possible. Once we are inside haweli, we are between the entire experiences of in-between - situated between entire groups of interiority. It is visually connected to the whole sequence of the interior spaces, running like a thread. Here, moving everywhere in both horizontal and vertical directions, one finds all dimensions of place real and tangible. The facade on all sides punctuated with verandahs, porches, sakoonchas, and aiwans and what even lies behind it, circumambulate and linger alongside the center of haweli - dark deep 
shaded windows of interior rooms drew us into the comfort of interior rooms, khana.

The courtyard is where all diversities of life come together; it is the center, which constitutes the ultimate "inside". The character of the inside is vivid and warm. Family activities populate this place and provide an architectural counterpart. Being familiar with its ambiance, there is an intense feeling of belonging, not because being there for the moment - but because being so much within its ambience - and memories that are so much with us - that we seem to belong to each other.

The center is the powerful focal point of the courtyard and is often explicitly marked by a fountain, a pool, or flower boxes. The idea of center finds multiple expressions in the courtyard house. As rooms open up and expand towards the edges, its inhabitants move accordingly and seat themselves around the periphery, allowing for an uninterrupted contemplation of the center. Of the more profound spatial provisions for such an intervention is the place of the aiwan, an open room that occupies the middle ground between the interior and exterior of the house and one that embraces the outer edge of the courtyard.

\section{Conclusion}

The defining universal values that are shared by the traditional architecture of Isfahan can help us reestablish meaning and a true sense of place. I will assign three values that appear to fulfill the criteria of relevance and deep attitudes that are essential to both arts of urban planning and architecture in the Islamic world. These distinctions are the following:

Tradition and spirituality: What differentiates a traditional urbanity from its modern counterpart is the belief that buildings are treated less as objects in the landscape, and more as conduit through which man can engage with his universe meaningfully and find spiritual fulfillment. The aim here is not so much aesthetic as it is experiential, meaning that what matters most to those societies who seek and preserve the integrity of urban form is less the image of things and more the way those very same things are able to connect individuals and bring a sense of purpose and spirituality to their presence on earth. In a place like Isfahan, this emphasis on connectivity is reflected in the way public square (Maidan), buildings and other public spaces are wrought together into a pattern of localizing spatial forces. While the modern spatial example is established on the premise that outside and inside constitute two different worlds, in Isfahan the two melt together into a singular conception of special space; here where there is society, community, there is no outside, only inside. Going from home, to street, to mosque, to bazaar, and back again, you do not go back and forth from inside to outside but remain in one world, from inside to inside, where you stay connected with others and protected from inimical forces. To be sure, going from home to street can be said to reflect the familiar scenario of going from inside to outside, but that is only true in pedantic terms; in spiritual terms and because of the fact that streets and public spaces are so inextricably linked with private 
buildings in the Muslim tradition, the situation is such that here one does not feel as if he or she is ever leaving, but only entering. And the consequences are that places like Isfahan ultimately work to first reduce hierarchy and second to eliminate the distinction between the sacred and the profane. In the view of tradition all inhabited spaces are considered sacred.

Being inside holds a special sway in the Muslim tradition. It is not only important spatially, giving the Muslim the means with which to maintain privacy and protect his family, but more importantly spiritually. To the medieval Muslim scholar IbnSina, to be inside was tantamount to being with god; whereas the outside world represented the world of appearances, a world defined by much corruption and vanity, the inside world reflected man's only capacity and only conduit with God [10]. Inside is a quiet, introspective and deeply pious world where both space and time dissolve in favor of the feeling of the eternal.

Tradition and nature: In view of tradition the transformation of nature should not summon an emotionless connotation, or an attainment of lust and greed for unconditional economic gain. To this end, the present trends of global developments and the resultant environmental degradation, the prospect of a new century raises serious questions about the health and viabilities of our civilization. In the last century with the abandonment of traditional built environment, towns and cities transformed significantly from an efficient human scale fabric to a sprawling low-density fragmentation, which adversely impacted our natural habitat. Most traditional cities and building practices evolved out of necessity and not a supply-driven ideology. Their sense of sustainability emerged from having found resonance with nature, its pace and cyclical progression. This way nature is never so transformed to the point to treat it as a residual quality and more as a body whose presence already has a system of built-in efficiency that if understood and appropriately manipulated can yield to a greater abundance. To this end traditional societies assign nature a sacred quality and treat it as a gift, not from another person or from a manufacturer, but from God, thereby placing it on equal footing with our deepest emotions and needs. This way when we come to displace nature from its origin, we do not do it with the idea of exploitation, where the end justifies the means, but with the idea that we have to take care in ensuring the continuation of a life already in process [11].

In this equation the making of architecture requires a conscious realignment of our hearts as well as our minds in order to intimately engage with properties of nature and acquire a unified totality. Architecture must be able to speak to the sun, to the wind, to the soil to the heat and to the cold; in short it must perpetuate the true spirit of place.

Tradition and community: Community is the setting up of the stage for human interactions to take shape, akin to the larger scheme and needs of the society. Here activities are seen as flowing and ebbing without resistance and without the pressure of operating under the hegemony of contesting goals. Like an organism, society finds maturity in the way it leaves itself open to changing conditions and to the unknown down the line. 
Tradition never enters into the definition of the polarity between the regressive and the progressive; rather it takes shape through a list of activities and rituals whose whole aim is to perpetuate humanity and community from one generation to the next. Progress is never quite an autonomous endeavor to be taken up with intention and action, but something that is already underway and evolving behind the scenes. This means that nature here is considered just as much part of a progress as their animate counterparts and that when one extracts as much as a stone to build a house, one does not do so independent of progress but very much part of it. Unlike techno-cultures where success is hyperactively measured by the degree to which reality can be distorted, in traditional cultures progress is not considered the hegemony of man but man the hegemony of progress, which has its own pace and its own regulating ways [11].

In architectural terms, we find that traditional settlements are atoned to the above collective community cultural requirements, which is strengthened through social bonds and mutual responsibilities within the community. Here, architecture is conceived as being a living entity with its fluid and organic fabric that facilitate distinct needs of social and cultural requirements. Towns and cities are defined by dense townscapes that are firmly unified buildings and land uses showing a high degree of complexity and cohesiveness [12]. The result is a rich urban tissue endowed with much aesthetic appeal and distinguished cultural history. These settlements are cloaked in their organic spontaneity and fluidity that drive the design and create a sense of place which breeds community solidarity and cultivate a rich urban cultural fabric.

The globalized vision of $21^{\text {st }}$ century offers us tremendous cross-cultural opportunities to shape the built environments of cities in this vast global arena. But this opportunity also burdens us with greater responsibility and humility that our decisions must become knowledge based, more innovative and more sustainable. As we master the art of gaining access to knowledge of culture in a differentiated world and serve new societies, it is architecture that shapes the environment of global communities to live a noble life and maintain their cultural identity with dignity.

\section{References}

[1] Shills, Edward. On Tradition, p-22, The University of Chicago Press, 1981.

[2] Hanne Bergius in "Architecture as the Dionysian-Appollonian Process of Dada," Nietzsche and An Architecture of Our Minds, Getty Research Institute, Los Angeles, CA, 1999

[3] Kazimee, Bashir and Rahmani, Ayad. Place, Meaning and Form in the Architecture and Urban Structure of Eastern Islamic Cities, p- Edwin Mellen Press, Ltd, New York, 2003.

[4] Irving Wohlfarth in "Construction has the Role of Subconscious: Phantasmagorias of the master Builder," Nietzsche and an architecture of Our Minds, Getty Publishers, 1999 
[5] Oliver, Paul. (Binerism in Islamic City). Islamic Architecture and Urbanism, p.121-146. King Faisal University, Dammam, Saudi Arabia, 1983.

[6] Arabi, G. Hossein. Isfahan, Yasavoli Publishers, Tehran, Iran, 1999.

[7] Kazimee Bashir. "UNDER THE SHADOW OF WALLS: Place, Meaning and Form in the Islamic Architecture and Urban Structure of Isfahan," p.112-116, proceedings, ACSA International Conference, Istanbul, Turkey, ACSA Press, June 2001.

[8] Michell, George. Architecture of the Islamic World, Its History and Social Meanings, Thames and Hudson, 1995.

[9] Hoag, John D. Islamic Architecture, Electa/Rizzoli New York, USA, 1987.

[10] Auguste de Montequin, Francois. The Essence of Urban Existence in the World of Islam, Islamic Architecture and Urbanism, King Faisal University, p-43-64, Dammam, SA., 1983.

[11] Kazimee, Bashir and Rahmani, Ayad. Place, Meaning and Form in the Architecture and Urban Structure of Eastern Islamic Cities, Edwin Mellen Press, Ltd, New York, 2003.

[12] Kazimee, Bashir. Learning from vernacular architecture: sustainability and cultural conformity. "Eco - Architecture: Harmonization between Architecture and Nature", pp 3-13, edited by G. Broadbent \& C.A. Brebbia, WIT Press, UK, 2008. 